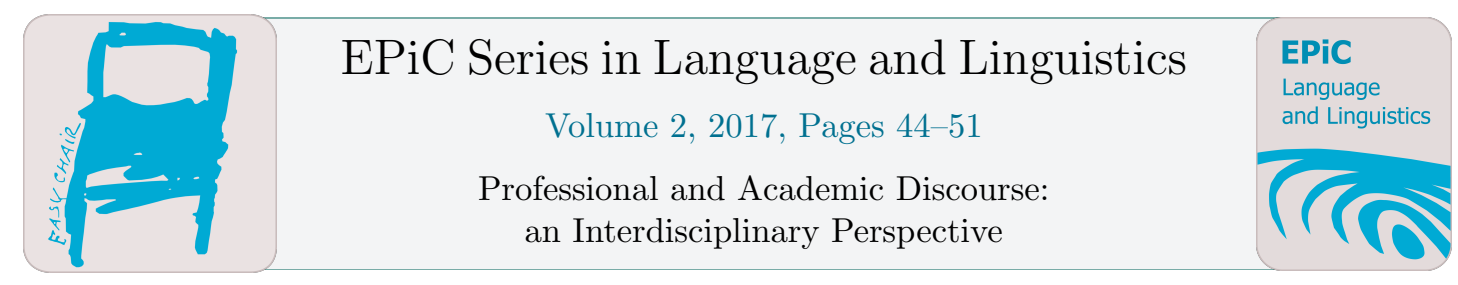

\title{
Culture Learning in B1 and B2 EFL Textbooks
}

\author{
Ángela Larrea-Espinar and Antonio Raigón-Rodríguez \\ Universidad de Córdoba, Spain \\ angela.larrea@uco.es, antonio.raigon@uco.es
}

\begin{abstract}
The interrelationship between language and culture has a direct bearing on language teaching. Our study focuses on the cultural analysis of textbooks. We have analysed 6 B1 and B2- level textbooks for teaching English to adults in Spain. To this aim, we have used a model of cultural learning analysis based on the earlier work of Paige and Lee. This functional framework gathers every category and aspect of culture needed to develop each of the competencies that are required to accomplish comprehensive culture learning.

Findings show that the invisible aspect of culture (small "c" target-culture learning), which is crucial to understanding the values and ways of thinking of a society, receives less coverage in textbooks. Regarding the comparison between B1 and B2 levels, the data indicate that the number of big "C" Culture occurrences is similar for both levels, although there are differences in other cultural aspects. Thus, despite some promising changes in the way of addressing culture learning in EFL textbooks, we are still far from developing intercultural speakers.
\end{abstract}

\section{Introduction}

The conviction that language and culture are two inseparable sides of the same coin has a direct bearing on language teaching: "Language and culture are not separate, but are acquired together, with each providing support for the development of the other" (Mitchell and Myles, 2004: 235). Despite this interrelationship, cultural teaching was a neglected component of language teaching in the 20th century until the advent of the communicative approach in the 1980s, which renewed and reinforced the link between language and culture. The cultural diversity implicit in globalisation, however, means that communicative competence proves insufficient for our desire to interact with people of different origin (Larzen-Ostermark, 2009). Thus, intercultural communicative competence (ICC) is the ability "to ensure a shared understanding by people of different social identities, and [the] ability to interact with people as complex human beings with multiple identities and their own individuality" (Byram, Gribkova and Starkey, 2002: 10). Intercultural competence, therefore, "involves looking at culture as not just knowledge, but also a set of skills, behaviors, and attitudes that help a person 
succeed in a cross-cultural environment" (Watson, Siska and Wolfel, 2013: 64). In this sense, the ability to decentralise and a positive attitude are the pillars that sustain intercultural communication.

In the case of teaching English as a foreign language, various studies have looked at the cultural component in textbooks. Numerous authors in Spain have addressed the subject of the cultural dimension in textbooks and other materials for learning foreign languages, among them Puig (1996), Areizaga (2002) and Paricio (2005). Outside Spain the subject has attracted wider attention: Kramsch (1988), Risager (1991), Sercu (2000), Lee (2009), Zarei and Khalessi (2011), Weninger and Kiss (2013), McConachy and Hata (2013).

In terms of the way culture is treated in textbooks, one of the main problems to have been identified is that cultural teaching is limited to the objective transmission of information (Kramsch, 1993). Cerezal (1999) argues that cultural teaching in many textbooks is oriented towards the acquisition of linguistic competence, to the detriment of pragmatic and sociocultural competences. This leads to a fragmented and stereotyped view of the foreign culture.

In Europe, the teaching of English as a foreign language is organised in accordance with the guidelines set out in the Common European Framework of Reference (Council of Europe, 2001). Despite the fact that the Framework recognises and endorses the acquisition of a cultural component, it does not establish specific descriptors for how this is to be achieved.

Thus, the present study uses our own cultural learning model based on previous research by Paige, Jorstad, Paulson, Klein and Colby (1999) and Lee (2009).Our model keeps Lee's (2009) threefold division of cultural aspects: culture in general, big " $\mathrm{C}$ " culture and small "c" culture. The taxonomies are based on Lee (2009) but we have simplified and reduced the number of items to provide a more sensible tool for recollection of data. We also divided the occurrences according to the skills involved (reading, listening, speaking or writing).

In the case of culture in general, learning is focused on the acquisition of knowledge, skills and attitudes of a more general character that are transferable to other cultures. The distinction between attitudes, behavior, and knowledge is a conceptual viewpoint that shows the affective, behavioral, and cognitive domains of learning (Paige et al., 1999).

Big "C" culture encompasses easily-observable events and statistics related to art, history, education, festivals, customs, etc. Examples of small "c" culture, on the other hand, include sociocultural values, norms, beliefs, assumptions, etc., which are less visible.

As for the materials, we have focused on books for teaching English as a foreign language to adults. Three publishers with a high reputation in the field of English teaching for adults in Spain were chosen, each with a significant share of the Spanish market: Oxford, Macmillan and Cambridge. The authors restricted the study to B1 (Intermediate) and B2 (Upper Intermediate) textbooks:

i. Oxford: English File Intermediate (2013) and New English File Upper-Intermediate (2008) .

ii. Cambridge: English Unlimited Intermediate (2011) and English Unlimited Upper Intermediate (2011).

iii. Macmillan: Straightforward Intermediate (2012) and Straightforward Upper Intermediate (2012).

The choice of these two levels was determined by the fact that level B1 is the threshold for a traveller visiting a foreign country (known as the "threshold" level) and the level required of university students in order to graduate, while B2 is the advanced or "vantage" level, which university students need in order to have access to the most common foreign-study grants (Erasmus +, for example). The editions were the most recent at the time the study was conducted.

The study uses a quantitative approach based on the observation of cultural occurrences, i.e., the activities that were conducive or related to culture learning. The authors of this study coded the data. The cultural occurrences were categorized and recorded as shown in the tables. When an activity was found to deal with more than one cultural aspect, the same activity has been recorded under the different cultural categories. For example, in English File (2013) the listening on page 41 (an English 
woman married to a Russian) is recorded in the three cultural categories ('culture in general', big ' $\mathrm{C}$ ' and little 'c').

Each table sets out the various categories proposed for learning that aspect of culture, the name of the textbook, its level and the frequency of cases found in the book.

For the purposes of analysing the cultural learning content, only the textbooks themselves were studied, ignoring any complementary course material such as CD-Roms, workbooks, websites, online activities etc. The only exception to this was the English File Intermediate textbook, where a series of videos and songs were included because they are presented in the textbook as activities that should be undertaken in the classroom, something that did not apply in the other cases. The additional material was not included in the research due to the nature and length of this work, but it is interesting enough to be considered for future research.

The objectives of the study were the following for each cultural aspect:

1. To compare the number of occurrences by level

2. To compare the number of occurrences by series

3. To identify the most frequently recurring theme by level

\section{Analysis}

\subsection{Cultural Aspect: Culture in General}

1) Comparison of the number of occurrences by level:

The B1 books include 167 examples of general cultural learning. In the B2 textbooks, 140 occurrences of learning cultural in general were found.

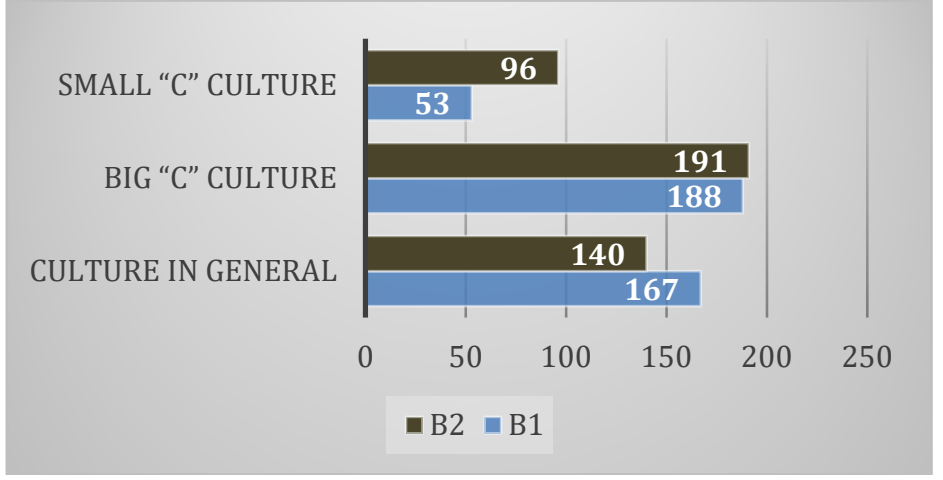

Figure 1:Total number of cultural occurrences classified by level and cultural aspect

Therefore, comparison of the two levels showed that culture in general is addressed more in B1level books than their B2 counterparts.

2) Comparison of the number of occurrences by series:

The number of occurrences of culture in general in English File $(E F)$ is much higher at B1 than at B2. This may be due to the fact that $E F$ is the only one of the three titles chosen for the study with different publication dates. The intermediate book dates from 2013, while the upper intermediate book dates from 2008. This leads the authors to conclude that the new edition incorporates more content featuring culture in general.

The number of occurrences of culture in general in English File is much higher at B1 than at B2. This may be due to the fact that $E F$ is the only one of the three titles chosen for the study with different publication dates. The intermediate book dates from 2013, while the upper intermediate book 
dates from 2008.In the case of English Unlimited (EU), the B1 level shows fewer occurrences than B2. With Straightforward (SF), the opposite is the case, with a greater number of occurrences at the lower level (B1).

\begin{tabular}{|c|c|c|c|c|c|c|c|}
\hline \multicolumn{2}{|c|}{ CULTURE IN GENERAL } & $E F$ & $\overline{E U}$ & $S F$ & $E F$ & $E \boldsymbol{E}$ & SF \\
\hline \multirow[t]{4}{*}{ Knowledge } & Cultural learning & 28 & 14 & 20 & 12 & 38 & 15 \\
\hline & Cultural adjustment stages (Shock) & 2 & 3 & & 1 & 3 & \\
\hline & Intercultural development & 1 & 5 & & & 11 & 9 \\
\hline & Cultural identity & 8 & 19 & 14 & 6 & 15 & \\
\hline \multirow[t]{4}{*}{ Behavior } & Culture learning strategies & 1 & 2 & & & 6 & \\
\hline & $\begin{array}{l}\text { Strategies dealing with intercultural } \\
\text { stress }\end{array}$ & & 1 & & & 2 & \\
\hline & Communicative & 1 & 2 & & & 8 & \\
\hline & Cultural adaptability & 1 & 3 & & & 3 & \\
\hline \multirow[t]{2}{*}{ Attitudes } & $\begin{array}{llll}\begin{array}{l}\text { Positive attitude toward cultural } \\
\text { learning }\end{array} & & \\
\end{array}$ & 17 & 13 & 1 & 2 & 9 & 2 \\
\hline & $\begin{array}{l}\text { Positive attitude toward cultural } \\
\text { differences }\end{array}$ & 2 & 8 & 1 & 1 & 7 & \\
\hline
\end{tabular}

Table 1: Total incidences. Culture in General.

3) Identifying the most frequently recurring theme by level

As far as the most frequently recurring themes are concerned, there is hardly any difference when comparing textbooks issued by the same publisher, which keep the same themes for both B1 and B2, except in the case of $E F$.

Thus, the most frequently occurring themes were "Cultural learning" and "Cultural identity" for both levels, B1 and B2. However, at B2level the second theme is followed very closely by "Intercultural development". The knowledge dimension plays a predominant role in both levels.

\subsection{Cultural Aspect: Big “C” Culture}

1) Comparison of the number of occurrences by level:

A comparative study of the two levels suggest that there is no substantial difference between B1 and B2 in terms of incorporating content that addresses big "C" culture (188 at B1 vs 191 at B2).

\begin{tabular}{|l|l|l|l|l|l|l|}
\hline BIG “C” CATEGORIES & $\begin{array}{l}\boldsymbol{E F} \\
\text { E1 }\end{array}$ & $\begin{array}{l}\boldsymbol{E U} \\
\mathbf{B 1}\end{array}$ & $\begin{array}{l}\boldsymbol{S F} \\
\boldsymbol{B} 1\end{array}$ & $\begin{array}{l}\boldsymbol{E F} \\
\boldsymbol{B} 2\end{array}$ & $\begin{array}{l}\boldsymbol{E U} \\
\mathbf{B 2}\end{array}$ & $\begin{array}{l}\boldsymbol{S F} \\
\boldsymbol{B} 2\end{array}$ \\
\hline Ethnic groups & 2 & 17 & 3 & 3 & 14 & 2 \\
\hline Geography/history/politics/regional variations & 2 & 2 & 15 & 1 & 6 & 8 \\
\hline Arts/crafts/monuments and historical sites & 3 & 3 & 8 & 2 & 10 & 4 \\
\hline Literature, films, music and mass media & 27 & 7 & 12 & 15 & 9 & 10 \\
\hline Currency/shopping/market/industry/business & 2 & 1 & 4 & 2 & 11 & 4 \\
\hline Urban life/infrastructure/housing/transportation & 7 & 2 & 7 & 7 & 5 & 3 \\
\hline Education & 4 & & 1 & & 7 & \\
\hline Dress-style & 2 & & & 2 & 2 & 2 \\
\hline Food & 1 & 1 & 3 & & 4 & \\
\hline Festivals/celebrations/holidays/ceremonies & & & 1 & 1 & 7 & 1 \\
\hline
\end{tabular}




\begin{tabular}{|l|l|l|l|l|l|l|l|}
\hline Social customs & 8 & 15 & 10 & 8 & 13 & 6 \\
\hline Leisure/sports & 1 & 2 & 3 & & 2 & 6 \\
\hline Family & 1 & 7 & 1 & & 3 & 1 \\
\hline $\begin{array}{l}\text { Non-verbal com. (personal space, oculesics, } \\
\text { haptics...) }\end{array}$ & & 3 & & 1 & 4 & 1 \\
\hline
\end{tabular}

Table 2: Total incidences. Big “C” culture.

2) Comparison of the number of occurrences by series:

English Unlimited is the textbook that contains the highest number of examples of big "C" culture at the B2 level (98 as opposed to 60 cases at B1) and also shows the highest difference in the number of occurrences between B1 and B2.The other two books contain fewer occurrences of big "C" culture at the B2 level and more occurrences of B1. Moreover, they show similar figures for B1 and B2 occurrences.

3) Identifying the most frequently recurring theme by level

The most frequently recurring themes are also the same for both levels: "Literature, films, music and mass media", "Social customs" and "Ethnic groups". There is, however, a difference in the leastcovered themes: the least common at B1 were "Festivals/celebrations /holidays/ceremonies" and "Dress-style", while at B2 they were "Food" and "Family".

\subsection{Cultural Aspect: Small “c” Culture}

1) Comparison of the number of occurrences by level:

A comparison of the two levels shows that there is a substantial difference between B1 and B2 in terms of including content for learning small "c" culture. This type of learning is tackled more at the B2 than the B1 level, as the number of occurrences identified in the books demonstrates.

\begin{tabular}{|c|c|c|c|c|c|c|}
\hline SMALL “c” CATEGORIES & $\begin{array}{l}E F \\
\text { B1 }\end{array}$ & $\begin{array}{l}E U \\
B 1\end{array}$ & $\begin{array}{l}\text { SF } \\
\text { B1 }\end{array}$ & $\begin{array}{l}E F \\
B 2\end{array}$ & $\begin{array}{l}E U \\
B 2\end{array}$ & $\begin{array}{l}S F \\
B 2\end{array}$ \\
\hline Individualism/collectivism & & 3 & 1 & 1 & 4 & 1 \\
\hline Equality & 1 & 1 & 1 & & 6 & 2 \\
\hline Fairness & 1 & & & 3 & 6 & 3 \\
\hline Competition & 1 & 1 & & & 3 & 1 \\
\hline Materialism & & & 1 & 2 & 2 & 2 \\
\hline Confrontation & 4 & 5 & & & 5 & 1 \\
\hline Novelty oriented (newer is better) & & & & & 2 & \\
\hline Self-improvement & & 2 & & 1 & 3 & 2 \\
\hline Nurture (up-bringing, education) & 2 & 4 & & 1 & 9 & 1 \\
\hline Time & 1 & & & 1 & & \\
\hline Level of formality & 3 & & 1 & & 8 & 1 \\
\hline Com. styles: direct vs. indirect & 3 & 5 & & & 8 & \\
\hline Rules-regulation oriented & & 3 & 1 & 3 & 5 & \\
\hline Male-oriented & & 3 & & & & 2 \\
\hline Result-oriented & & 2 & & & 3 & 2 \\
\hline Importance of hard work & & 3 & & & 2 & \\
\hline
\end{tabular}

Table 3: Total incidences. Small“c” culture.

2) Comparison of the number of occurrences by series: 
The comparative data for books in the same series indicate that the English File series has a higher number of occurrences at the B1 level related to small "c" culture, precisely the opposite of what occurs with the other two series, which have more small "c" culture content at B2.This may be due to the fact that, as noted earlier, the B2 publication is older than its B1 counterpart.

3) Identifying the most frequently recurring theme by level

As far as the most-frequently recurring themes are concerned, there are differences between the levels. At the B1 level the most frequently recurring themes were "Confrontation" and "Communication styles: direct vs. indirect", while at B2 they were "Fairness" and "Nurture". At B1 there is a theme that was not covered at all, "Novelty oriented", whereas all the themes are covered at B2, with the least frequent being "Time" (with one occurrence).

\section{Discussion of Results and Conclusions}

The comparative analysis of the cultural occurrences classified both by level and cultural aspect showed that:

In general, the cultural aspect most covered by the textbooks is big "C" Culture, as is indicated by the total number of occurrences. Culture in general occupies second place while coverage of small "c" comes last.

Comparing the treatment of cultural aspects at the two levels, it is evident that there is no substantial difference between B1 and B2 in the frequency of big "C" Culture. This suggests that this aspect is covered more or less equally at both levels. There are differences, however, in the way the other cultural aspects are treated. The data indicate that at the B1 level more aspects of general culture are included whereas at the B2 level more aspects of small "c" culture are present. It may be the case that being B2 a higher level, it is easier for the learning material to incorporate subjective aspects, which require a greater degree of conceptualization.

Besides, the most complete title in terms of cultural acquisition, measured both by the categories covered and by the number of cultural occurrences, is English Unlimited, and this applies both to the B1 and the B2 publications. However, the B1 book would benefit from an increase in the number of occurrences and themes related to big "C" Culture, given that Straightforward Intermediate is slightly superior in this respect.

The present study confirmed earlier findings in relation to which cultural aspect is more commonly treated in textbooks. Lee's (2009) research into this question indicates that aspects related to big "C" predominate, i.e. the objective and visible elements of culture, to the detriment of culture in general and small "c" culture. Varón (2009) already noted this phenomenon, pointing out that the treatment of invisible culture in textbooks is limited in most cases to anecdotal and peripheral information.

Thus, although the treatment that culture receives in textbooks has changed for the better, including aspects of culture in general and small "c" culture, the invisible aspects of culture are the most neglected, despite the fact that they are essential for understanding a society's ways of thinking and values, providing insights that cannot be acquired if one is restricted to teaching big " $\mathrm{C}$ " Culture. Then, much remains to be done so that the cultural learning taking place is appropriate and conducive to the development of interculturally competent speakers and we can start by working on specific descriptors for culture learning. 


\section{References}

Areizaga, E. 2002. "El componente cultural en la enseñanza de lenguas: elementos para el análisis y la evaluación del material didáctico”. Cultura y Educación14 (2):161-175.

Byram, M. 1989. Cultural studies in foreign language education. Clevedon: Multilingual Matters. 1997. Teaching and assessing intercultural communicative competence. Clevedon:

Multilingual Matters.

Byram, M., B. Gribkova \& H. Starkey. 2002. Developing the intercultural dimension in language teaching: a practical introduction for teachers. Strasbourg: Council of Europe.

Cerezal, F. 1999. La transmisión de valores genéricos discriminatorios en libros de texto de inglés. Alcalá: Servicio de Publicaciones, Universidad de Alcalá.

Council of Europe. 2001. Common European framework of reference for languages: Learning, teaching, assessment. Cambridge: Cambridge University Press.

Kerr, P. \& C. Jones. 2012. Straightforward Intermediate. Oxford: MacMillan.

Kerr, P. \& C. Jones. 2012. Straightforward Upper Intermediate. Oxford: MacMillan.

Kramsch, C. 1988. "The cultural discourse of foreign language textbooks". In A. J. Singerman (ed.)1988 Toward a new integration of language and culture. Middlebury: Northeast Conference on the Teaching of Foreign Languages Inc. .1993. Context and culture in language teaching. Oxford: Oxford University Press. .1998. Language and culture. New York, NY: Oxford University Press.

Larzen-Östermark, E.2009. "Language teacher education in Finland and the cultural dimension of foreign language teaching - a student teacher perspective”. European Journal of Teacher Education32: 401-21.

Latham-Koenig, C. \& C. Oxenden. 2013. English File Intermediate. Oxford: Oxford University Press.

Lee, K. Y. 2009. "Treating culture: What 11 high school EFL conversation textbooks in South Korea do”. English Teaching: Practice and Critique 8 (1): 76-96.

.2012. "Teaching intercultural English learning/teaching in world Englishes". English Teaching: Practice and Critique11 (4): 190-205.

McConachy, T. \&K. Hata. 2013. "Addressing textbook representations of pragmatics and culture”. ELT Journal67 (3): 294-301.

Mitchell, R., \&F. Myles. 2004. Second language learning theories. London: Arnold.

Oxenden, C. \& C. Latham-Koenig. 2008. New English File Upper-Intermediate. Oxford: Oxford University Press.

Paige, R., J. Jorstad, L. Paulson, F. Klein\&J. Colby. 1999. "Culture learning in language education: A review of the literature”. In R. Paige, D. Lange, \& Y. Yershova (eds.) 1999Culture as the core: Integrating culture into the language curriculum. Minneapolis, MN: The Center for Advanced Researchon Language Acquisition, University of Minnesota.

Paricio, S. 2005. "La dimensión cultural en los libros de texto de lenguas extranjeras: Pautas para su análisis”. Glosas Didácticas15: 133-144.

Puig, G. 1996. " Analyse du contenu ethnoculturel des manuels de langues étrangères ». Diálogos Hispánicos18: 327-346.

Rea, D. \& T. Clementson. 2011. English Unlimited Intermediate. Cambridge: Cambridge University Press.

Risager, K. 1991. "Cultural references in European textbooks: An evaluation of recent tendencies”. In D. Buttjes \& M. Byram (eds.) 1991Mediating Languages and Cultures. Clevedon: Multilingual Matters.

Sercu, L. 2000. “Textbooks”. In M. Byram (ed.) 2000Routledge encyclopedia of language teaching and learning. London and New York, NY: Routledge. 
Tilbury, A. \& L. A. Hendra. 2011. English Unlimited Upper Intermediate. Cambridge: Cambridge University Press.

Varón, M. E. 2009. “Componente cultural, libros de texto y enseñanza del inglés como lengua extranjera”. Forma y Función22 (1): 95-124.

Watson, J., P. Siska \&R. L. Wolfel. 2013. "Assessing gains in language proficiency, cross-cultural compentence, and regional awareness during study abroad: A preliminary study”. Foreign Language Annals46 (1): 62-79.

Weninger, C. \&T. Kiss. 2013. "Culture in English as a foreign language (EFL) textbooks: A semiotic approach”. TESOL Quarterly47 (4): 694-716.

Zarei, G. R. \&M. Khalessi. 2011. "Cultural load in English language textbooks: An analysis of Interchange series”. Procedia - Social and Behavioral Sciences15: 294-301. 